DOI: 10.19195/0137-1150.166.9

\title{
NIKOŁAJ HANDOGA
}

Общецерковная аспирантура и докторантура имени святых равноапостольных Кирилла и Мефодия в Москве, Rosja

\section{Антропология святителя Викторина Петавийского: употребление терминов „homo", „Adam" и ,,secundus homo"}

Христос родился в тот же день, в который образовал человека (hominem); Он пострадал в тот же день, в который пал Адам (Adam), Он воскрес из мертвых в тот же день, в который сотворил свет (lucem) ${ }^{1}$.

Среди святых отцов и церковных писателей доникейского периода, писавших на латинском языке, особое место занимает святитель Викторин Петавийский (ок. 230-303/304) ${ }^{2}$. Он прославился в Церкви Христовой не только как один из мучеников, подобно святителю Киприану Карфагенскому (ок. 200/210-258) ${ }^{3}$ и многим другим истинным ученикам Христовым, но также как первый латинский толкователь Священного Писания (большинство его сочинений посвящено экзегезе библейских книг ${ }^{4}$ и первый хри-

${ }^{1}$ Victorinus Poetovionensis, Tractatus De fabrica mundi 9, 132-135, ред. R. Gryson, Turnhout 2017, с. 299 [перевод мой - Н.Х.].

2 День его памяти - 2/15 ноября (см. Месяцеслов дополнительный имен святых, не содержашихся в календаре Русской Православной Церкви, Москва 2013, с. 24; Сергий (Спасский), архим., Полный месячеслов Востока, т. 1: Восточная агиология, Москва 1997, с. 690-691). Однако нужно иметь в виду, что в этот день жители Петавия (современный город Птуй в Словении) из-за осады варварами в конце $\mathrm{V}$ в. их родного города перенесли мощи Викторина в Лавриак (современный город Лорх в Германии). См. M. Dulaey, Victorin de Poetovio. Premier exégète latin, Paris 1993, т. 1, c. 13; т. 2, c. 9.

${ }^{3}$ См. J. Doignon, ,, Nos bons hommes de foi”: Cyprien, Lactance, Victorin, Optat, Hilaire (Augustin. De doctrina christiana IV, 40, 61), „Latomus” № 22 (4), 1963, c. 803.

${ }^{4}$ См. Н.А. Хандога, Святитель Викторин Петавийский - первый латинский экзегет, „Скрижали” № 7, 2014, с. 52; D. Kasprzak, Wiktoryn z Poetovium - pierwszy chrześcijański egzegeta łaciński, „Analecta Cracoviensia” № 43, 2011, c. 147. 
стианский писатель-паннониец 5 . Кроме того, Викторин как „пастырь добрый” (Ин. 10:11) был учителем нравственности для петавийских христиан ${ }^{6}$ и, возможно, для всех христиан Верхней Паннонии ${ }^{7}$.

К великому сожалению, из обширного списка творений Викторина Петавийского, упоминавшихся в труде $O$ знаменитых мужах блаженного Иеронима Стридонского (ок. 347-419/420) ${ }^{8}$, сохранилось лишь одно сочинение - Толкование на Апокалипсис 9 . Однако Иероним пишет и о „многих других (multa alia)" "10 творениях Викторина, которые, возможно, он не читал, поэтому и не упомянул в своем сочинении. Среди них подлинными творениями Петавийского святителя исследователи считают следующие: трактат $O \mathrm{co}$ творении мира ${ }^{11}$ и фрагмент $O$ жизни Христа ${ }^{12}$. В настоящее время также известны неподлинные сочинения, приписываемые Викторину Петавийскому $^{13}$. Среди них особым авторитетом пользуется трактат $O$ десяти девах ${ }^{14}$, написанный Псевдо-Викторином Петавийским ${ }^{15}$.

В подлинных сочинениях Викторина особое внимание уделяется не ангелам, сотворенными Богом в первый и четвертый дни ${ }^{16}$, не животным, сотворенными Богом в пятый день ${ }^{17}$, а первому человеку, или Адаму, так как

${ }^{5}$ Cм. R. Bratož, Der Bischof Victorinus und die Kirchengemeinde von Poetovio (2. Hälfte des 3. Jahrhunderts), „Zalai Múzeum” № 11, 2002, c. 7; idem, Verske razmere v Petovioni v drugi polovici 3. stoletja v luči poročil škofa Viktorina, [в:] Ptuj v rimskem cesarstvu. Mitraizem in njegova doba, ред. М. Vomer Gojkovič, N. Kolar, Ptuj 2001, c. 313.

${ }^{6}$ Например, в толковании первых глав Откровения Иоанна Богослова он вместо исторической или буквальной экзегезы (см. в частности: Ианнуарий /Ивлиев/, архим., И увидел я новое небо и новую землю. Комментарий к Апокалипсису, Москва 2015, с. 43-80) использует аллегорическое или духовное толкование с целью донести до читателей основы христианской нравственности. См. Victorinus Poetovionensis, Explanatio in Apocalypsin I, 138-236, ред. R. Gryson, Turnhout 2017, с. 130-144.

7 См. Ю.К. Колосовская, Паннония в I-III веках, Москва 1973, с. 206.

${ }^{8}$ См. Hieronymus Stridonensis, De viris illustribus 74, ред. M.E. Botecchia Deho, Roma 2009 , c. $348-349$.

${ }^{9}$ Cм. Victorinus Poetovionensis, Explanatio in Apocalypsin..., c. 110-264.

${ }^{10}$ Hieronymus Stridonensis, De viris illustribus 74..., c. 348.

${ }^{11}$ Cм. Victorinus Poetovionensis, Tractatus De fabrica..., c. 295-300.

${ }^{12}$ См. Victorinus Poetovionensis, Fragmentum De vita Christi, ред. R. Gryson, Turnhout 2017, c. 303.

${ }^{13}$ Cм. M. Dulaey, Victorin de Poetovio. Premier exégète latin..., т. 1, c. 42-50; т. 2, c. 21-26.

${ }^{14}$ См. Pseudo-Victorinus Poetovionensis, De decem virginibus, ред. M. Veronese, Roma 2002, с. 352-357; idem, De decem virginibus, ред. М. Špelič, Celje 1999, c. 168-175.

${ }^{15}$ См. R. Gryson, Répertoire general des auteurs ecclésiastiques latins de l'antiquité et $d u$ haut moyen age, т. 1, Freiburg 2007, c. 813.

16 См. Н.А. Хандога, Космология святителя Викторина Петавийского: сотворение ангелов, животных и первых людей, „Труди Київської духовної академії” № 24, 2016, с. 143148.

17 См. Н.А. Хандога, Космология святителя Викторина Петавийского: богословскофилологический анализ латинских терминов, „Вестник Екатеринбургской духовной семинарии” № 2 (18), 2017, с. 22-23; idem, Космология святителя Викторина Петавийского: сотворение ангелов..., с. 148-150.

Slavica Wratislaviensia 166, 2018

(C) for this edition by CNS 
именно он являлся венцом Божьего творения ${ }^{18}$, и Новому Адаму, или Господу Иисусу Христу, так как именно Он спас человечество от власти диавола ${ }^{19}$. Другими словами, Бог „за шесть дней из ничего (sex diebus ex nihilo)"20 coтворил мир ради первого человека, или первых людей и, когда пришло время, „отдал Сына Своего Единородного, дабы всякий, верующий в Него, не погиб, но имел жизнь вечную" (Ин. 3:16). Следовательно, антропология Викторина излагается в трактате $O$ сотворении мира, а также частично в Толковании на Апокалипсис. Что касается фрагмента О жизни Христа, то он будет интересен тем, кто занимается вопросом символической аритмологии святых отцов и церковных писателей. Исходя из этого, целью данной статьи является раскрытие учения о человеке Викторина Петавийского, то есть богословскофилологический анализ цитат, в которых употребляются термины „һото”, „Adam” и „secundus homo”.

\section{1. Термин „,hото”}

Викторин Петавийский, основываясь на книгах Бытие, Псалтирь, Евангелие от Иоанна как главных источниках, сообщает, что Бог Отец с Сыном Божиим, но не с Духом Святым „сотворил все (omnia fecit)”, то есть мир, или вселенную. Все дело в том, что Викторин отождествлял второе и третье Лица Святой Троицы, так как был сторонником бинитаризма ${ }^{21}$. Однако в отличие от других христианских писателей (например, Тертуллиана /ок. 155-160 после 220/22 и Лактанция /ок. 250-260 — после 325/23) он достаточно часто приводил четкую грань между Сыном Божиим и Духом Святым ${ }^{24}$.

В шестой день Бог сотворил „человека из земли (hominem de humo)” и наделил его властью быть владыкой „всех существ, которых Он создал на земле и в воде (omnium rerum quas super terram et super aquam creauit)",25, то

18 См. Н.А. Хандога, Космология святителя Викторина Петавийского: богословско-филологический анализ..., с. 23-25; idem, Космология святителя Викторина Петавийского: сотворение ангелов..., с. 150-152.

19 См. Victorinus Poetovionensis, Tractatus De fabrica..., 9, c. 126-127, 299.

20 Victorinus Poetovionensis, Tractatus De fabrica..., 1, 5, с. 295.

21 См. А.Р. Фокин, Латинская патрология, т. 1, период первый: Доникейская латинская патрология (150-325 г2.), Москва 2005, с. 264-265; idem, Викторин Петавский [Петавийский], [в:] Православная энцчиклопедия, т. 8, под ред. Патриарха Московского и всея Руси Алексия II, Москва 2004, с. 459-460.

22 См., в частности: Tertullianus, De oratione 1, ред. A. Reifferscheid, G. Wissowa, Pragae-Vindobonae-Lipsae 1890, c. 180.

23 См., в частности: Lactantius, Divinae institutiones IV, 6, ред. S. Brandt, Pragae-Vindobonae-Lipsae 1890, c. 286.

24 С. Victorinus Poetovionensis, Explanatio in Apocalypsin II, 206-225, c. 172-176.

25 Victorinus Poetovionensis, Tractatus De fabrica..., 4, 42-43, c. 296. 
есть всего животного мира, существующего в воде, на земле и в воздухе ${ }^{26}$. В этом Викторин Петавийский продолжает линию апостола Павла († 67):

Ибо не ангелам Бог покорил будущую вселенную, о которой говорим; напротив, некто негде засвидетельствовал, говоря: «что значит человек, что Ты помнишь его? или сын человеческий, что ты посещаешь его? не много ты унизил его пред ангелами; славою и честью увенчал его, и поставил его над делами рук Твоих, все покорил под ноги его». Когда же покорил ему все, то не оставил ничего непокоренным ему (Евр. 2:5-8).

Вот почему в центр мироздания Богом поставлен человек, а не ангелы, которые были созданы Господом в предыдущие дни.

Однако возникает естественный вопрос: первый человек был сотворен Господом в один или в два этапа, как об этом упоминается в книге Бытие (см. Быт. 2:7)? Для того, чтобы ответить на этот вопрос, нужно проанализировать все фрагменты трактата $O$ сотворении мира, в которых согласно богословской терминологии творения Викторина раскрывается действие Божие в отношении человека ${ }^{27}$, или употребляются термины „instruxit”28 и ,finxit" 29 :

В шестой день было создано (creata) то, чего недоставало, вот так Бог воздвиг (instruxit) человека из земли (см. Быт. 2:7) как господина всех существ, которых Он создал (creauit) на земле и в воде (см. Быт. 1:28). Однако прежде <Бог> сотворил (creauit) ангелов и архангелов, $<$ после> образовал ( finxit) человека, полагая духовное раньше земного; ведь свет <появился> прежде, чем небо и земля (ср. Быт. 1:1) ${ }^{30}$.

\section{Или в другом месте мы читаем:}

„Он ${ }^{31}$ обратился в плоть в тот же день, в который воздвиг (instruxit) человека из земли; Христос родился в тот же день, в который образовал ( finxit) человека... ${ }^{32}$

\section{Кроме того, в одном фрагменте он использует только один термин:}

26 Однако Викторин категорически отрицает идею сотворчества человека Господу на уровне творения мира. Вероятно, потому, что для него оно было связано с античной теургией, то есть представлением о том, что люди не только могут соучаствовать в божественных деяниях, но также подчинять богов своей воле. См. А.В. Петров, Феномен теургии. Взаимодействие языческой философии и религиозной практики в эллинистическо-римский период, Санкт-Петербург 2003, с. 200.

27 См. Н.А. Хандога, Космология святителя Викторина Петавийского: богословско-филологический анализ..., с. 25-26.

28 Этот термин происходит от глагола „іnstruere”, который означает воздвигать, возводить. И.Х. Дворецкий, Латинско-русский словарь, Москва 1976, с. 538; Oxford Latin Dictionary, ред. P.G.W. Glare, Oxford 1968, с. 931.

29 Этот термин происходит от глагола ,fingere”, который означает образовывать, формировать. И.Х. Дворецкий, Латинско-русский..., с. 428; Oxford Latin..., с. 702. H.X.]

${ }^{30}$ Victorinus Poetovionensis, Tractatus De fabrica..., 4, 40-45, с. 296 [перевод мой -

31 То есть Дух Святой, а правильно - Сын Божий.

32 Victorinus Poetovionensis, Tractatus De fabrica..., 9, 131-133, c. 299 [перевод мой H.X.].

Slavica Wratislaviensia 166, 2018

(C) for this edition by CNS 
Таким образом, это Слово называется [...] благочестием — когда Оно образовало ( finxit) человека... ${ }^{33}$

Следовательно, первый человек был создан Богом в два этапа: первый - Господь воздвиг, или вылепил его из земли (поэтому в каждом человеке есть вся таблица Менделеева; естественно, в очень небольших пропорциях), а второй - образовал, или наделил его особыми свойствами, которых нет даже у млекопитающих (например, умениями разговаривать и прямо ходить; естественно, первому человеку не нужно было этому учиться).

Тем не менее, когда Викторин Петавийский хочет „обойти стороной” вопрос двух этапов сотворения Богом человека, то употребляет термин ,fabricaret" 34 :

Однако именно поэтому <Бог> окончил Свои дела прежде, чем сотворил (crearet) ангелов и создал (fabricaret) человека, чтобы <еретики> лживой речью не настаи <ва>ли, будто ангелы были <в этом> Его помощниками ${ }^{35}$.

Кроме того, этим Викторин подчеркивает разницу в творении ангелов и человека, так как „из терминов он выбирает не „сreatio”, в котором есть некие оттенки рождения, не „оріficium”, что могло бы натолкнуть на известные архитектурные смыслы и чрезмерное подчеркивание значимости твари, но „fabrica”, которое происходит от „faber” - кузнец, соответственно, первоначальное значение существительного „fabrica” — кузнечное дело, то есть создание изделия, качественно отличного от первоначальной руды, и, соответственно, оно несет в себе смыслы качественного изменения и творения из ничего" 36 .

Следовательно, первый человек был сотворен Господом отличным от всех живых существ и совершенным ${ }^{37}$ в шестой день. Однако начиная с первых дней Бог уже приготовлял для него мир:

В начале Бог сотворил свет (Быт. 1:1; см.: Быт. 1:3) и разделил его двенадцатеричным числом <ч>асов на день и ночь - для того, очевидно, чтобы день приводил себе на смену ночь как место покоя от трудов людских, а затем вновь побеждал бы день, и так, взаимно чередуясь, труд подкреплялся бы покоем <ночи>, а покой вновь чередовался бы с дневной деятельностью.

33 Ibidem, 7, 104-105, 108, с. 298 [перевод мой - Н.Х.].

34 Этот термин происходит от глагола ,fabricare”, который означает создавать, образовывать. И.Х. Дворецкий, Латинско-русский..., с. 410; Oxford Latin ..., с. 665.

${ }^{35}$ Victorinus Poetovionensis, Tractatus De fabrica..., 4, 48-50, c. 296 [перевод мой H.X.].

${ }^{36}$ Н.А. Хандога, Космология святителя Викторина Петавийского: четверица и седмерица как структурообразующие принципы мира, „Христианское чтение” № 4, 2015, с. 9.

37 Это, например, проявилось в том, что он до грехопадения, во-первых, давал имена животным в соответствии с их качествами (см. Быт. 2:19-20) и, во-вторых, что он знал прошедшее и будущее (см. Быт. 2:22-23). 
В четвертый день <Бог> создал два светила на небе, большее и меньшее, чтобы одно управляло днем, а другое - ночью (Быт. 1:16), солнце и луну, и прочие звезды поместил на небе, чтобы светили над землей (Быт. 1:17) и различали времена и годы, и месяцы, и дни, и часы (см.: Быт. 1:14) <своим> местонахождением $<$ на небе $>38$.

Таким образом, Викторин Петавийский, раскрывая учение о первом и четвертом днях творения, с которых начался отсчет времени, то есть появились первые часы и дни, упоминает о двенадцати часах дня и двенадцати часах ночи, которые предназначены Богом для труда и отдыха людей. Поэтому справедливо замечание словенского профессора Райко Братожа: „Экзегеза творения в эти два дня отражает антропоцентризм авторского подхода, согласно которому создание человека должно быть конечной целью Божественной заботливости" 39 .

\section{2. Термин „Adam”}

В шестой день, или в пятницу ${ }^{40}$ Бог сотворил первого человека, а точнее - первых людей, или первых мужчину и женщину (см. Быт. 1:27):

Ведь Адама $($ Adam $)<$ Бог> совершенствовал (consummauit) ${ }^{41}$ по образу и подобию Своему (см.: Быт. 1:26) ${ }^{42}$.

\section{И в другом месте мы читаем:}

Кто таким образом научен в законе Божием, кто исполнен Духом Святым, да не презрит сердцем того, что ангел Гавриил благовествовал Марии-деве (см. Лк. 1:28) в тот же день, в который дракон совратил Еву... Он (то есть Господь Иисус Христос - Н. Х.) пострадал в тот же день, в который пал Адам $($ Adam $) . .43$

Следовательно, имя первых людей - Адам и Ева.

В первом приведенном фрагменте есть два важных момента. Во-первых, так как Господь сотворил первого человека совершенным (см. Быт. 1:27), то земля в течение пяти дней, предшествовавших его творению, приготовлялась Богом для человека в качестве царского чертога ${ }^{44}$. Во-вторых, так как H.X.].

${ }^{38}$ Victorinus Poetovionensis, Tractatus De fabrica..., 2, 12-20, с. 295 [перевод мой -

${ }^{39}$ R. Bratoz, Il cristianesimo Aquileiese prima di Constantino fra Aquileia e Poetovio, Udine - Gorizia 1999, c. 302; idem, Krščanstvo v Ogleju in na vzhodnem vplivnem območju oglejske cerkve od začetkov do nastopa verske svobode, Ljubljana 1986, c. 299.

${ }^{40}$ См. Victorinus Poetovionensis, Tractatus De fabrica..., 4, 40, 46, c. 296.

41 Этот термин происходит от глагола „соnsummare”, который означает совершенствовать, доводить до совершенства. И.Х. Дворецкий, Латинско-русский..., с. 248; Oxford Latin..., c. 424.

42 Victorinus Poetovionensis, Tractatus De fabrica..., 4, 47-48, c. 296 [перевод мой - Н.X.].

${ }^{43}$ Victorinus Poetovionensis, Tractatus De fabrica..., 9, 125-127, 133-134, c. 299 [перевод мой - Н.X.].

${ }^{44}$ Cp. Grégoire de Nysse, La création de l’homme 2, ред. J. Laplace, J. Daniélou, Paris 1944, c. 90 . 
Иероним Стридонский называет Викторина Петавийского „подражателем Оригена и исследователем его экзегетического наследия (возможно, был переводчиком его на латинский язык), 45 , то вероятно, что вслед за Оригеном 46 под образом и подобием Божиим (см.: Быт. 1:26) Викторин Петавийский имеет в виду усовершенствование через уподобление Богу, или „благочестие” (pietatis) ${ }^{47}$, поскольку это характеристика шестого неба, которое соответствует в его типологии шестому дню творения.

Во втором приведенном фрагменте есть также два важных момента. Во-первых, сначала согрешила Ева (поэтому понадобилась Новая Ева, или Мария-дева, которая смогла исправить ее „ошибку”), а после нее согрешил Адам (поэтому понадобился Новый Адам, или Господь Иисус Христос, который смог исправить его „ошибку”), так как они в раю нарушили единственную Господню заповедь о невкушении плодов с ,дерева познания добра и зла" (Быт. 2:17). Во-вторых, в результате грехопадения все перевернулось „с ног на голову”, то есть первые люди и их потомки перестали быть владыками на земле, а также стали подверженными болезням, старению и смерти.

Однако и после грехопадения Бог продолжал любить свое самое величайшее творение - первых людей, так как сразу же дает им обетование о приходе в мир Спасителя:

И вражду положу между тобой [то есть диаволом - Н.Х.] и между женой, и между семенем твоим и между семенем ее; оно будет поражать тебя в голову, а ты будешь жалить его в пяту (Быт. 3:15).

Тем не менее, прошло много времени пока исполнилось это пророчество $^{48}$.

В творениях Викторина Петавийского данное пророчество также нашло свое отражение:

Для того, чтобы восстановить (reformauerit $)^{49}$ Адама через седмицу, а также прийти на помощь всему Своему творению, <Бог> совершил это посредством рождения Сына Своего Иисуса Христа, Господа нашего ${ }^{50}$.

${ }^{45}$ И. Панагопулос, Толкование Священного Писания у отцов Церкви, т. 1. Первые три века и александрийская экзегетическая традииия до пятого века, пер. с греч., послесл. свящ. Максима Михайлова, Москва 2013, с. 395.

${ }^{46}$ См. Origène, Contre Celse 4, 30, ред. М. Borret, Paris 1968, с. 254-256.

47 Victorinus Poetovionensis, Tractatus De fabrica..., 7, 92, c. 298.

48 Согласно восьмидневной, или восьмитысячной концепции Викторина Петавийского, изложенной в трактате $O$ сотворении мира, прошло пять тысяч лет. См. Н.А. Хандога, Восьмидневная концепщия святителя Викторина Петавийского, „Труды Минской духовной академии" № 13, 2016, с. 218-219.

49 Этот термин происходит от глагола „reformare”, который означает восстанавливать, отстраивать. И.Х. Дворецкий, Латинско-русский..., с. 862; Oxford Latin..., с. 1596.

${ }^{50}$ Victorinus Poetovionensis, Tractatus De fabrica..., 9, 123-125, с. 299 [перевод мой H.X.]. 
Однако здесь спасительные деяния Господа Иисуса Христа символически соединяет с двумя планами, то есть творением мира и падением первых людей ${ }^{51}$ :

Кто таким образом научен в законе Божием, кто исполнен Духом Святым, да не презрит сердцем того, что ангел Гавриил благовествовал Марии-деве (см.: Лк. 1:28) в тот же день, в который дракон совратил Еву; Дух Святой преисполнил Марию-деву в тот же день, в который сотворил свет; Он обратился в плоть в тот же день, в который сотворил сушу и море; Он обратился в молоко в тот же день, в который сотворил звезды; Он обратился в кровь в тот же день, в который суша и море произвели свои порождения; Он обратился в плоть в тот же день, в который воздвиг человека из земли; Христос родился в тот же день, в который образовал человека; Он пострадал в тот же день, в который пал Адам; Он воскрес из мертвых в тот же день, в который сотворил свет? ${ }^{52}$.

\section{Или в другом месте мы читаем:}

...ведь когда первый человек (primus homo) погиб на дереве, то через дерево страдания он был возвращен ${ }^{53}$.

Бесспорно, эта концепция связана, во-первых, с теорией рекапитуляции святителя Иринея Лионского (ок. 130-140 - 202/203) ${ }^{54}$, который главную ее мысль, то есть что Христос — Глава спасаемого человечества, заимствовал у апостола Павла (см.: Рим. 5:12-15, 18-21) 55 , и, во-вторых, с античной теорией о развитии эмбриона, встречающейся, например, у блаженного Августина Гиппонского (354-430) 56 , для которого, как и для Викторина Петавийского, особую важность имело число семь и четыре этапа формирования эмбриона 57 . Следовательно, Новый Адам, или Господь Иисус Христос исполнил волю Божию в тот самый день, в который Адам ее нарушил, то есть в седьмой день, или в субботу.

51 Важно отметить, что по учению Викторина Петавийского, „Господь Иисус Христос прожил на земле такую же жизнь, как любой другой человек, живший когда-либо". Н.А. Хандога, Хронология земной жизни Господа нашего Иисуса Христа по сохранившимся сочинениям святителя Викторина Петавийского - „О сотворении мира” и „Хронологический фрагмент”, „Труди Київської духовної академії” № 26, 2017, с. 258.

52 Victorinus Poetovionensis, Tractatus De fabrica..., 9, 125-135, с. 299 [перевод мой H.X.].

53 Idem, Explanatio in Apocalypsin II, 122-123, с. 160 [перевод мой - Н.Х.].

54 См. Irenaeus Lugdunensis, Adversus haereses 3, 16, 6; 18, 7; 21, 10; 22, 3, ред. A. Rousseau, L. Doutreleau, Paris 1974, c. 310-314, 364-370, 426-430, 438.

55 См. M. Marin, Note sul simbolismo aritmologico di Vittorino di Petovio, [в:] Italia e romania. Storia, cultura e civiltà a confront, ред. S. Santelia, Bari 2004, с. 203.

${ }^{56}$ См. Aurelius Augustinus, De diversis quaestionibus octaginta tribus liber unus 56, ред. J.P. Migne, Paris 1865, c. 39.

${ }^{57}$ См. M.H. Congourdeau, L'embryon et son âme dans les sources grecques (VI-e siècle av. J.-c. - V-e siècle apr. J.-c.), Paris 2007, c. 227. 


\section{3. Термин „secundus homo"}

С одной стороны, в шестой день, или в пятницу был сотворен Богом первый человек, или Адам, а с другой стороны, в этот же день родился Спаситель мира - Господь Иисус Христос ${ }^{58}$. Его Викторин Петавийский именует вторым человеком или одним из человеческого рода:

Следовательно, Оно есть Первородный (primus) <всякого> творения (ср.: Кол. 1:15), второй человек (secundus hominis) < или один> из рода человеческого, как говорит апостол (cp.: 1 Kop. 15:47) ${ }^{59}$.

\section{Или в другом месте Его он именует новым человеком:}

В человеке воспринятом Он дал свидетельство в мире, пострадав в котором, освободил нас от греха Своею кровью и, победив ад, первый (primus) воскрес из мертвых, и смерть над Ним более не будет властвовать, но в Его правление царство мира было разрушено ${ }^{60}$.

Следовательно, Господь Иисус Христос есть первый как творческое Слово, через которое все начало быть, рожденное от Бога Отца прежде всякого творения; Он же есть и последний как второй Адам, небесный Человек, родоначальник нового человечества.

Исходя из этого, Викторин Петавийский ясно и четко различает человеческую и Божественную природу Господа Иисуса Христа и в то же время объединяет их в рамках единой Личности. Во-первых, Христос - совершенный человек:

Он также иудеям показывает Свою человеческую природу (humanitatem suam) следующими способами: когда голоден (см. Мф. 4:2), жаждет (см. Ин. 4:7), когда принимает пищу и питие (см. Лк. 7:34), когда ходит (см. Мф. 4:18) и удаляется (см. Ин. 6:15; Мф. 4:12), когда спит на изголовье <лодки> (см. Мк. 4:38) 61 .

\section{И в другом месте мы читаем:}

Он также исполняет Свою человеческую природу (humanitatem suam) числом семь: рождение, младенчество, отрочество, юность, молодость, зрелость, смерть ${ }^{62}$.

\section{И, во-вторых, Христос обладает Божественными свойствами:}

Когда же во время поднявшейся бури на море ходит пешком <по воде> (см. Ин. 6:18-19; Мф. 14:22-25), когда повелевает ветрам (см. Лк. 8:25), исцеляет больных (см. Мф. 12:15) и восстанавливает хромых (см. Мф. 15:31), <слепых делает зрячими (см. Мф. 15:31), глухих

58 См. Victorinus Poetovionensis, Tractatus De fabrica..., 9, 132-133, c. 299.

59 Ibidem, 7, 103-104, c. 298 [перевод мой - Н.X.].

${ }^{60}$ Victorinus Poetovionensis, Explanatio in Apocalypsin I, 13-17, c. 112 [перевод мой H.X.].

${ }^{61}$ Victorinus Poetovionensis, Tractatus De fabrica..., 9, 137-140, c. 299 [перевод мой H.X.].

62 Ibidem, 9, 135-137, с. 299 [перевод мой - Н.Х.]. 
— слышащими и немых $\longrightarrow$ красноречивыми (см. Мк. 7:37), то разумей, что Он возвещает им о Себе как о Господе (Dominum) ${ }^{63}$.

Позднее (то есть после I Константинопольского собора /381г./) подобные доказательства неоднократно использовались святыми отцами и церковными писателями в борьбе против монофизитов и, в том числе против константинопольского архимандрита Евтихия (ок. 378-454). Поэтому, пожалуй, не будет преувеличением утверждать, что данный фрагмент $O$ сотворении мира Викторина Петавийского лежит у истоков той традиции, которая привела к появлению догматического послания, или „Томоса”, святителя Льва I Великого (между 380 и 390-461) ${ }^{64}$, в котором «с особой выразительностью оттенялось учение о полноте двух естеств во Христе» ${ }^{65}$.

\section{Заключение}

Викторин Петавийский в трактате $O$ сотворении мира и частично в Толковании на Апокалипсис предлагает интересную антропологию. С одной стороны, он утверждает, что в шестой или последний творческий день Бог сотворил только человека, а точнее первых людей - Адама и Еву. С другой стороны, он считает, что свет, солнце, луна и звезды, сотворенные Господом в первый и четвертые дни исключительно ради всего человеческого рода, так как с их помощью люди ежедневно имеют время для труда и отдыха.

Анализируя подлинные сочинения Викторина, может показаться, что он из терминов использует только три - „homo”, „Adam” и „secundus hото”, однако это совсем не так. Для того, чтобы приоткрыть тайну творения первого человека, или Адама, он употребляет следующие глаголы: „instruxit”, „finxit”, „fabricaret”, „,consummauit” и „,reformauerit”. В результате чего мы узнаем, что первый человек был сотворен Богом в два этапа и отличается от других живых существ, а также, что ему потребовалась помощь Божия, чтобы вернуть утраченное величие.

Важным моментом антропологии Викторина Петавийского является ее связь с христологией, так как он символически соединяет шестидневное творение и грехопадение первых людей с воплощением Сына Божия. Например, в шестой день Бог сотворил первого человека и в этот же день родился Спаситель мира. Кроме того, когда Петавийский святитель употре-

63 Ibidem, 9, 140-143, с. 299 [перевод мой - Н.Х.].

${ }^{64}$ См. М.Н. Гаврилов, Св. Лев Великий: жизнь и учение, в связи с его эпохой и со смыслом его иерковного почитания в православных богослужебных книгах, Брюссель 1996, c. $36-37$.

${ }^{65}$ А.П. Лебедев, Вселенские Соборы IV и V вв.: обзор их догматической деятельности в связи с направлениями школ Александрийской и Антиохийской, Санкт-Петербург 2007, c. 232.

Slavica Wratislaviensia 166, 2018

(C) for this edition by CNS 
бляет термин „,secundus homo”, он имеет в виду второго Адама, или небесного Человека. Поэтому исключительно ради голгофской жертвы Господа Иисуса Христа люди снова именуются венцами Божьего творения.

\section{Библиография}

Гаврилов М.Н., Св. Лев Великий: жизнь и учение, в связи с его эпохой и со смыслом его иерковного почитания в православных богослужебных книгах, Брюссель 1996.

Дворецкий И.Х., Латинско-русский словарь, Москва 1976.

Ианнуарий (Ивлиев), архим., И видел я новое небо и новую землю. Комментарий к Апокалипсису, Москва 2015.

Колосовская Ю.К., Паннония в I-ІІІ веках, Москва 1973.

Лебедев А.П., Вселенские Соборы IV и V вв.: обзор их догматической деятельности в связи с направлениями школ Александрийской и Антиохийской, Санкт-Петербург 2007.

Месяцеслов дополнительный имен святых, не содержащихся в календаре Русской Православной Церкви, Москва 2013.

Панагопулос И., Толкование Священного Писания у отщов Церкви, т. 1. Первые три века и александрийская экзегетическая традиия до пятого века, пер. с греч., послесл. свящ. Максима Михайлова, Москва 2013.

Петров А.В., Феномен теургии. Взаимодействие языческой философии и религиозной практики в эллинистическо-римский период, Санкт-Петербург 2003.

Сергий (Спасский), архим., Полныій месячеслов Востока, т. 1: Восточная агиология, Москва 1997.

Фокин А.Р., Викторин Петавский [Петавийский], [в:] Православная энциклопедия, т. 8, под ред. Патриарха Московского и всея Руси Алексия II, Москва 2004.

Фокин А.Р., Латинская патрология, т. 1, период первый: Доникейская латинская патрология (150-325 гг.), Москва 2005.

Хандога Н.А., Восмидневная концепция святителя Викторина Петавийского, „Труды Минской духовной академии” № 13, 2016.

Хандога Н.А., Космология святителя Викторина Петавийского: богословско-филологический анализ латинских терминов, „Вестник Екатеринбургской духовной семинарии” № 2 (18), 2017.

Хандога Н.А., Космология святителя Викторина Петавийского: сотворение ангелов, животных и первых людей, „Труди Київської духовної академіі”” № 24, 2016.

Хандога Н.А., Космология святителя Викторина Петавийского: четверица и седмерица как структурообразующие принцииьы мира, „Христианское чтение” № 4, 2015.

Хандога Н.А., Святитель Викторин Петавийский - первый латинский экзегет, „Скрижали” № 7, 2014.

Хандога Н.А., Хронология земной жизни Господа нашего Иисуса Христа по сохранившимся сочинениям святителя Викторина Петавийского — „О сотворении мира” и „Хронологический фрагмент”, „Труди Київської духовної академії” № 26, 2017.

Aurelius Augustinus, De diversis quaestionibus octaginta tribus liber ипиs, ред. J.-P. Migne, Paris 1865.

Bratoz R., Der Bischof Victorinus und die Kirchengemeinde von Poetovio (2. Hälfte des 3. Jahrhunderts), „Zalai Múzeum” № 11, 2002.

Bratoz R., Il cristianesimo Aquileiese prima di Constantino fra Aquileia e Poetovio, Udine-Gorizia 1999.

Bratoz R., Krščanstvo v Ogleju in na vzhodnem vplivnem območju oglejske cerkve od začetkov do nastopa verske svobode, Ljubljana 1986.

Slavica Wratislaviensia 166, 2018

(C) for this edition by CNS 
Bratoz R., Verske razmere v Petovioni v drugi polovici 3. stoletja v luči poročil škofa Viktorina, [в:] Ptuj v rimskem cesarstvu. Mitraizem in njegova doba, ред. М. Vomer Gojkovič, N. Kolar, Ptuj 2001.

Congourdeau M.H., L'embryon et son âme dans les sources grecques (VI-e siècle av. J.-c. - V-e siècle apr. J.-c.), Paris 2007.

Doignon J., ,Nos bons hommes de foi”: Cyprien, Lactance, Victorin, Optat, Hilaire (Augustin. De doctrina christiana IV, 40, 61), „Latomus” № 22 (4), 1963.

Dulaey M., Victorin de Poetovio. Premier exégète latin, т. 1-2, Paris 1993.

Grégoire de Nysse, La création de l'homme, ред. J. Laplace, J. Daniélou, Paris 1944.

Gryson R., Répertoire general des auteurs ecclésiastiques latins de l'antiquité et du haut moyen âge, т. 1, Freiburg 2007.

Hieronymus Stridonensis, De viris illustribus 74, ред. M.E. Botecchia Deho, Roma 2009.

Irenaeus Lugdunensis, Adversus haereses, ред. А. Rousseau, L. Doutreleau, Paris 1974.

Kasprzak D., Wiktoryn z Poetovium - pierwszy chrześcijański egzegeta taciński, „Analecta Cracoviensia” № 43, 2011.

Lactantius, Divinae institutiones, ред. S. Brandt, Pragae-Vindobonae-Lipsae 1890.

Marin M., Note sul simbolismo aritmologico di Vittorino di Petovio, [в:] Italia e romania. Storia, cultura e civiltà a confront, ред. S. Santelia, Bari 2004.

Origène, Contre Celse, ред. M. Borret, Paris 1968.

Oxford Latin Dictionary, ред. P.G. W. Glare, Oxford 1968.

Pseudo-Victorinus Poetovionensis, De decem virginibus, ред. M. Špelič, Celje 1999.

Pseudo-Victorinus Poetovionensis, De decem virginibus, ред. M. Veronese, Roma 2002.

Tertullianus, De oration, ред. A. Reifferscheid, G. Wissowa, Pragae-Vindobonae-Lipsae 1890.

Victorinus Poetovionensis, Explanatio in Apocalypsin, ред. R. Gryson, Turnhout 2017.

Victorinus Poetovionensis, Fragmentum De vita Christi, ред. R. Gryson, Turnhout 2017.

Victorinus Poetovionensis, Tractatus De fabrica mипdi, ред. R. Gryson, Turnhout 2017.

\section{The antropology of Saint Victorinus of Poetovio: Consumption of terms homo, Adam and secundus homo}

\section{Summary}

Victorinus of Poetovio discloses in treatise On the creation of the world and partly in Commentary on the Apocalypse, the doctrine of how the God in six days created the world out of nothing and made a special place to the first human being. He chooses three terms: homo, Adam and secundus homo. As a result, we find out that the first man was Adam, who had a woman named Eve. An important point is that God created first people not on first days, but on the sixth, when everything in the world, or the Universe, was being prepared for the coming. According to the teachings of the Victorinus, on that day the Creator did not do anything else, as all kinds of animals, by the command of God, appeared on the fifth day. Moreover, the first man was created by God as a special one, since in the world of the living creatures there is no more than one similar to the Creator, and also not in one, but in two stages.

Keywords: anthropology, saint Victorinus of Poetovio, treatise On the Creation of the World, Commentary on the Apocalypse, the sixth day of creation, the first man. 


\section{Антропологія святителя Вікторина Петавійського: використання термінів „homo”, „Adam” i „secundus homo"}

Резюме

Вікторин Петавійський розкриває в трактаті Про створення світу і частково в „Тлумаченні Апокаліпсису” вчення про те, як Бог за шість днів із нічого створив світ і виділяє особливе місце першій людині. Із термінів він вибирає три — „homo”, „Adam” i „secundus homo". У результаті чого ми дізнаємось, що першу людину звали Адам, в якого була жінка, яку звали Єва. Важливим моментом $є$ те, що Бог створив першу людину не в один із перших днів, а в шостий, так як все в світі, або Всесвіті готувалось для її приходу. За вченням Вікторина, у цей день Творець більше нічого не творив, отже, всі види тварин, по повелінню Божому, з'явились в п'ятий день. Крім того, перша людина була створена Богом особливою, так як більше немає на світ ні одного із живих створінь, подібних до Творця, а також не в один, а в два етапи.

Ключові слова: антропологія, святитель Вікторин Петавійський, трактат Про створення світу, Тлумачення Апокаліпсису, шостий день творіння, перша людина. 